\title{
Disolusi Terbanding Tablet Asetaminofen Produk Generik Berlogo dan Produk Bermerek
}

\section{Compared Disolution of Acetaminophen Generic Products and Brand Products}

\begin{tabular}{|c|c|}
\hline & ABSTRAK \\
\hline $\begin{array}{l}\text { Tuti Sri Suhesti*, } \\
\text { Eka Prasasti Nur } \\
\text { Rachmani } \\
\text { Jurusan Farmasi, } \\
\text { Universitas Jenderal } \\
\text { Soedirman. } \\
\text { Jalan Dr. Soeparno, } \\
\text { Karangwangkal, } \\
\text { Purwokerto } \\
\text { nailyfa@gmail.com } \\
\text { Kata kunci: } \\
\text { asetaminofen, obat } \\
\text { generik, uji disolusi, } \\
\text { dapar fosfat }\end{array}$ & $\begin{array}{l}\text { Asetaminofen/parasetamol adalah obat analgetik-antipiretik yang populer dan banyak } \\
\text { digunakan. Sediaan asetaminofen dalam bentuk tablet, selain dengan nama generik juga } \\
\text { tersedia dengan nama dagang. Tujuan penelitian ini adalah untuk mengetahui ekivalensi in } \\
\text { vitro terhadap mutu produk dagang dan generik berlogo tablet asetaminofen yang beredar di } \\
\text { pasaran. Pada penelitian ini dilakukan uji disolusi terbanding asetaminofen produk obat } \\
\text { generik berlogo dan produk bermerek dalam media disolusi berupa larutan dapar fosfat pH } \\
5,8 \text {. Penentuan laju disolusi asetaminofen dilakukan menggunakan metode paddle (dayung) } \\
\text { dengan kecepatan pengadukan } 50 \mathrm{rpm} \text {, pada suhu } 37^{\circ} \mathrm{C} \pm 0,5^{\circ} \mathrm{C} \text {. Sampel cuplikan diambil } \\
\text { pada menit ke } 5,10,15,20,30 \text { dan } 45 \text {. Parameter uji yang diamati adalah kadar obat terlarut } \\
\text { pada saat } \mathrm{t}=30 \text { menit }\left(\mathrm{C}_{30}\right) \text { dengan parameter standar baku } \mathrm{C}_{30} \text { menunjukkan hasil tidak boleh } \\
\text { kurang dari } 80 \% \text { kadar obat. Hasil penelitian didapatkan bahwa disolusi tablet } \\
\text { asetaminofen masing-masing produk baik obat generik berlogo maupun produk } \\
\text { bermerek menunjukan gambaran profil disolusi yang berbeda. Dari } 8 \text { sampel diperoleh } 5 \text { produk } \\
\text { paten dan } 3 \text { produk generik semuanya menunjukkan hasil disolusi dengan nilai } \mathrm{C}_{30} \text { yang } \\
\text { memenuhi syarat }(\geq 80 \text { ). }\end{array}$ \\
\hline $\begin{array}{l}\text { Keywords: } \\
\text { Acethaminophen, } \\
\text { generic, brand } \\
\text { product, disolution, } \\
\text { buffer phospat }\end{array}$ & $\begin{array}{l}\text { Acetaminophen is a popular and widely used analgesic-antipyretic drug. Acetaminophen } \\
\text { preparations in tablet form, in addition to generic names, are also available under the trade } \\
\text { name. The purpose of this study was to determine the in vitro equivalence to the quality of } \\
\text { commercial products and generic tablet logo acetaminophen on the market. In this research, } \\
\text { the result of the dissolution test of acetaminophen generic drug product with logo and } \\
\text { branded product in dissolution media such as phosphate buffer pH 5,8. Determination of } \\
\text { the rate of dissolution of acetaminophen was done using paddle method (paddle) with } 50 \\
\text { rpm stirring speed, at } 37^{0} C \pm 0,5^{\circ} C \text {. The sample samples were taken at } 5,10,15,20,30 \text { and } \\
45 \text { minutes. The test parameters observed were the dissolved drug level at time } t=30 \\
\text { minutes (C30) with the standard parameter C30 showing the results should not be less than } \\
80 \% \text { The results showed that the dissolution of acetaminophen tablets of each product both } \\
\text { generic drugs with logo and branded products showed different dissolution profile pictures. } \\
\text { From } 8 \text { samples obtained } 5 \text { patent products and } 3 \text { generic products, all showed dissolution } \\
\text { results with a qualified C } 30 \text { ( } \geq 80) \text {. }\end{array}$ \\
\hline
\end{tabular}




\section{Pendahuluan}

Asetaminofen atau parasetamol adalah obat analgesik-antipiretik yang populer dan banyak digunakan untuk meredakan sakit kepala, sakit ringan, dan demam. Asetaminofen banyak digunakan dalam sebagian besar resep karena aman dalam dosis standar. Dari pengukuran kualitas farmasetika suatu sediaan yang mengandung bahan aktif dan dosis yang sama serta rute pemberian yang sama tidak menjamin memberikan ketersediaan farmasetika yang sama. Hal ini disebabkan oleh modifikasimodifikasi formulasi yang dalakukan oleh masing-masing pabrik. Laju pelepasannya merupakan tahap yang paling menentukan kecepatan bioavailabilitas obat.

Ketika suatu obat orisinal atau produk pertama pemilik hak paten yang biasanya sekaligus sebagai pihak yang menemukan obat dipasarkan ke tengahtengah masyarakat, obat tersebut pastinya telah melewati serangkaian pengujian ilmiah. Produk sejenis yang kita kenal dengan obat generik atau generik bermerek ini agar memiliki khasiat dan keamanan yang sama dengan obat orisinalnya, maka mereka harus memenuhi syarat bioekivalen. Artinya ketika seorang pasien mengonsumsi suatu obat, baik yang berupa produk orisinal maupun generiknya, pasien tersebut akan mendapatkan efek yang sama.

Bioekivalensi obat ini menjadi penting dikarenakan apabila obat orisinal dan obat generik diberikan ke pasien dalam bentuk zat berkhasiat murni tanpa bahan tambahan lain, bioekivalensi tidak akan menjadi masalah karena dapat dipastikan kedua obat tersebut akan memberikan efek yang sama. Dalam praktiknya tidaklah seperti itu, karena obat tidak hanya terdiri dari zat berkhasiat saja, melainkan dicampur dengan bahanbahan lain. Di samping perbedaaan terhadap bahan tambahan, perbedaan dalam proses pembuatan juga akan mempengaruhi suatu obat. Maka mungkin kita pernah mendengar atau mengalami ada dokter yang hanya mau memakai obat merek tertentu yang mungkin salah satu alasannya adalah masalah keyakinan ini.

Tablet asetaminofen yang beredar ada yang dipasarkan dengan nama generik atau dengan non-generik (nama dagang/merek). Tablet asetaminofen yang beredar di pasaran memiliki harga yang berbeda-beda (Anonim, 2002). Penyebab perbedaan harga tablet asetaminofen ini adalah multifaktorial.

Oleh karena itu, perlu dilakukan penelitian apakah perbedaan harga ada hubungannya dengan perbedaan mutu. Jika terbukti bahwa mutu tablet asetaminofen generik setara dengan mutu tablet asetaminofen non-generik, maka diharapkan dapat mendorong keberhasilan penggunaan tablet asetaminofen generik di pelayanan kesehatan, baik sektor publik maupun swasta dan sebaliknya.

Tujuan penelitian ini adalah untuk membandingkan mutu beberapa tablet asetaminofen $500 \mathrm{mg}$ generik berlogo (OGB) dengan non generik/ bermerek yang beredar di pasaran dan untuk mengetahui ada atau tidak adanya perbedaan proporsi dalam hal terpenuhinya syarat baku antara tablet asetaminofen $500 \mathrm{mg}$ generik dengan non-generik yang beredar di pasaran berdasar uji availabilitasnya secara in vitro. 


\section{Bahan dan Metode}

\section{Bahan}

Bahan-bahan yang digunakan yaitu asetaminofen standar (Bratachem), aquabidest (Brataco), kalium dihidrogen fosfat (Merck), kloroform p.a. (Merck), 5 produk sampel tablet asetaminofen generik dan 3 produk sampel non-generik, metanol p.a.

\section{Pengambilan sampel}

Sampel yang akan diteliti adalah tablet asetaminofen $500 \mathrm{mg}$ yang beredar di pasaran yang terdiri atas 3 produk tablet generik berlogo dan 5 merek tablet non generik/patent. Sampel tablet asetaminofen $500 \mathrm{mg}$ diambil dari apotik dimana setiap sampel terdiri atas 20 tablet.

\section{Penetapan kadar tablet asetaminofen}

Larutan standar asetaminofen dibuat dengan konsentrasi $100 \mu \mathrm{g} / \mathrm{ml}$ dan diukur serapannya dengan spektrofotometer UV-Vis pada panjang gelombang $284 \mathrm{~nm}$. Pembuatan kurva baku dilakukan dengan membuat larutan standar dengan cara $100 \mathrm{mg}$ asetaminofen ditimbang seksama, dimasukkan ke dalam labu takar 100,0 ml, dilarutkan dengan metanol $10 \mathrm{ml}$, diencerkan dengan air hingga batas tanda (larutan 1000 $\mu \mathrm{g} / \mathrm{ml})$.

Larutan $1000 \mu \mathrm{g} / \mathrm{ml}$ dipipet $10,0 \mathrm{ml} \mathrm{ke}$ dalam labu takar 100,0 ml, diencerkan hingga batas tanda (larutan $100 \mu \mathrm{g} / \mathrm{ml}$ ). Larutan $100 \mu \mathrm{g} / \mathrm{ml}$ dipipet $10,0 \mathrm{ml} \mathrm{ke}$ dalam labu takar 50,0 ml, diencerkan hingga batas tanda (diperoleh konsentrasi $20 \mu \mathrm{g} / \mathrm{ml}$ ). Kemudian dibuat seri larutan dengan konsentrasi 20, 40, 50, 60, 80 dan $100 \mu \mathrm{g} / \mathrm{ml}$.
Sejumlah 10 tablet ditimbang dan dihitung bobot rata-ratanya, kemudian digerus hingga halus. Ditimbang seksama serbuk tablet setara dengan $100 \mathrm{mg}$ asetaminofen anhidrat dimasukkan ke dalam labu takar 100,0 ml, dilarutkan dengan $10 \mathrm{ml}$ metanol, diencerkan dengan air hingga batas tanda dan dikocok homogen (larutan a). Larutan (a) dipipet $1,0 \mathrm{ml}$ ke dalam labu takar $10,0 \mathrm{ml}$, diencerkan hingga batas tanda dan diukur pada panjang gelombang serapan maksimum $\left(\lambda_{\max }=243 \mathrm{~nm}\right)$, terhadap air sebagai blanko.

\section{Uji disolusi}

Larutan buffer $\mathrm{pH}$ 5,8 dibuat dengan cara melarutkan 27,7 g kalium dihidrogen fosfat dalam 3 liter aquabidest, $\mathrm{pH}$ diatur hingga 5,8 $\pm 0,1$ dengan ammonium hidroksida pekat. Medium disolusi (larutan dapar fosphat $\mathrm{pH} 5,8$ ) 900,0 mL dimasukkan ke dalam labu disolusi, pengaduk dayung (paddle) diatur pada kecepatan $50 \mathrm{rpm}$ dengan jarak pengaduk basket dari dasar adalah $2,5 \mathrm{~cm}$

Suhu percobaan dipertahankan berada pada $37 \pm 0,5^{\circ} \mathrm{C}$. Sampel diambil pada menit ke 5, 10, 15, 20, 30 dan 45 sebanyak 5,0 mL. Sampel yang diambil diganti dengan medium disolusi baru dalam jumlah yang sama sehingga volume medium disolusi tetap. Sampel diukur serapannya pada spektrofotometer $\lambda_{\max }$ asetaminofen.

\section{Analisis data}

Penentuan parameter disolusi obat terlarut, dengan perhitungan jumlah asetaminofen terlarut pada waktu 30 menit $\left(\mathrm{C}_{30}\right)$. Standar USP menyatakan bahwa kadar asetaminofen terlarut tidak boleh kurang dari $80 \%$ terhadap kadar yang tercantum pada label. Pembuatan grafik profil pelepasan asetaminofen masing-masing formula 


\section{Hasil dan Pembahasan}

\section{Penetapan kadar tablet asetaminofen}

Penetapan kadar zat aktif dilakukan dengan metode spektrofotometri karena asetaminofen memiliki gugus kromofor yang dapat menyerap pada panjang gelombang di daerah UV yaitu spektrum larutan pada panjang gelombang 200-400 nm (Rohman, 2007). Panjang gelombang maksimum dan kurva baku asetaminofen ditentukan dalam larutan media disolusi (dapar phosphat $\mathrm{pH}$ 5,8) digunakan untuk penetapan kadar pada uji disolusi. Hasil scanning panjang gelombang maksimum yaitu $284 \mathrm{~nm}$.

Hasil pengamatan absorbansi seri larutan baku asetaminofen dalam pelarut dapar fosfat disajikan dalam tabel 1.

Tabel 1. Data kurva baku asetaminofen

\begin{tabular}{cc}
\hline \multicolumn{2}{c}{ Pelarut media disolusi } \\
\hline $\begin{array}{c}\text { Konsentrasi } \\
\text { asetaminofen (ppm) } \\
(\mathbf{m g} / \mathbf{m l})\end{array}$ & $\begin{array}{c}\text { Absorbansi } \\
\boldsymbol{\mathbf { m a x }}=\mathbf{2 8 4 n m} \\
\mathbf{n m})\end{array}$ \\
\hline 20 & 0,127 \\
40 & 0,315 \\
50 & 0,367 \\
60 & 0,454 \\
80 & 0,603 \\
100 & 0,695 \\
\hline
\end{tabular}

Hubungan kadar asetaminofen dengan absorbansi pada media disolusi ditunjukkan dengan persamaan garis regresi linear:

$\mathrm{y}=7,121 \cdot 10^{-3} \mathrm{x}+0,011$ dengan $\mathrm{r}=0,994$
Dari persamaan kurva baku diperoleh persamaan garis linier (garis lurus). Hal ini menunjukkan bahwa linearitas grafik kurva baku memenuhi hukum LambertBeer sehingga dapat digunakan dalam penetapan konsentrasi asetaminofen dalam sediaan (Rohman, 2007).

\section{Uji disolusi}

Uji disolusi dilakukan menggunakan media dapar fosfat $\mathrm{pH}$ 5,8. Terdapat beberapa cara pengungkapan hasil uji pelepasan pelarutan obat, yaitu metode klasik Ct (jumlah zat terlarut pada saat tertentu), dissolution efficiency (DE) dan tetapan kecepatan pelarutan (k) (Khan, 1975). Berdasarkan data disolusi pada masing-masing produk diperoleh hasil pelepasan asetaminofen dengan data yang disajikan pada tabel 2.

Tabel 2. Kadar uji disolusi tablet asetaminofen dari berbagai produk

\begin{tabular}{|c|cccccccc|}
\hline Waktu & \multicolumn{7}{|c|}{ Kadar Asetaminofen Terlarut (mg) } \\
(menit) & P1 & $\mathbf{P 2}$ & $\mathbf{P 3}$ & $\mathbf{P 4}$ & $\mathbf{P 5}$ & $\mathbf{G 1}$ & $\mathbf{G 2}$ & $\mathbf{G 3}$ \\
\hline 0 & 0 & 0 & 0 & 0 & 0 & 0 & 0 & 0 \\
5 & 310,74 & 185,06 & 327,59 & 252,47 & 496,10 & 106,94 & 280,55 & 380,96 \\
10 & 371,83 & 320,57 & 569,13 & 496,10 & 588,79 & 227,19 & 369,02 & 432,91 \\
15 & 393,59 & 489,79 & 568,42 & 582,47 & 603,53 & 352,87 & 386,57 & 515,06 \\
20 & 465,91 & 466,62 & 527,70 & 597,91 & 610,55 & 359,19 & 413,96 & 508,74 \\
30 & 480,66 & 532,62 & 545,96 & 557,89 & 550,87 & 395,70 & 443,45 & 446,25 \\
45 & 400,62 & 512,25 & 578,96 & 578,25 & 593,70 & 417,47 & 451,87 & 499,62 \\
\hline
\end{tabular}

Keterangan: P : Produk patent/ bermerek $\mathrm{G}$ : Produk generik

Berdasarkan data di atas dapat dibuat profil hubungan antara konsentrasi asetaminofen terlarut dengan waktu, yang dapat dilihat pada gambar 2 . 


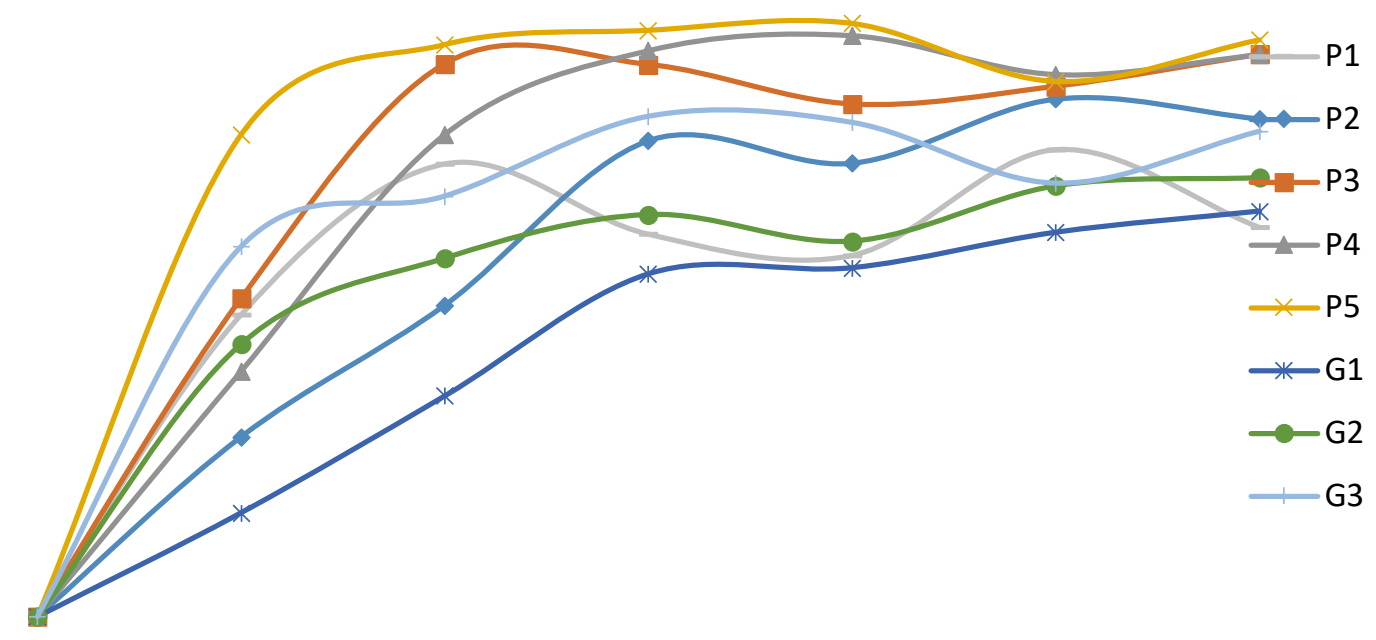

Gambar 1. Profil disolusi Asetaminofen dari berbagai produk

Tabel 3. Kadar obat terdisolusi (\%)

\begin{tabular}{ccrrrrrr}
\hline Waktu & \multicolumn{7}{c}{ Kadar obat terlarut (\%) } \\
\hline 0 & 0 & 0 & 0 & 0 & 0 & 0 & 0 \\
5 & 62,148 & 37,012 & 65,518 & 50,493 & 99,22 & 21,3886 & 56,11 \\
10 & 93,182 & 64,114 & 113,825 & 99,22 & 117,757 & 45,438 & 73,804 \\
15 & 78,718 & 97,957 & 113,684 & 116,493 & 120,706 & 70,574 & 82,791 \\
20 & 74,365 & 93,323 & 105,54 & 119,582 & 122,11 & 71,838 & 77,314 \\
30 & 96,131 & 106,523 & 109,191 & 111,578 & 110,174 & 79,14 & 88,689 \\
45 & 80,123 & 102,45 & 115,791 & 115,65 & 118,74 & 83,493 & 90,374 \\
\hline
\end{tabular}

Perbedaan profil disolusi masingmasing produk terkait dengan formulasi sediaan dari masing-masing produk, baik dipengaruhi dari bahan tambahan (eksipien) yang digunakan, metode pembuatan dan proses pembuatannya yang berbeda untuk tiap-tiap produsen.

Jumlah asetaminofen terlarut berdasarkan perhitungan C30 menunjukkan gambaran disolusi asetaminofen dengan pola yang berbeda, dimana disolusi asetaminofen dari 8 sampel diperoleh 5 produk paten dan 3 produk generik dengan nilai $\mathrm{C}_{30}$ yang memenuhi syarat $(\geq 80 \%)$. Nilai disolusi Ct (C30) dipilih sebagai parameter yang digunakan dalam pengungkapan hasil data uji disolusi asetaminofen, hal ini berdasarkan gambaran profil yang memenuhi syarat juga adanya syarat batasan nilai standar c30 yang diacu dalam USP (United States Pharmacope) XXIII yang menyatakan bahwa disolusi tablet asetaminofen pada waktu ke 30 (menit) tidak boleh kurang dari 80\% kadar asetaminofen. 


\section{Simpulan}

Dari hasil penelitian yang dilakukan dapat diambil kesimpulan yaitu semua tablet asetaminofen $500 \mathrm{mg}$ generik dan non-generik yang diperiksa memenuhi syarat baku menurut USP XXVI. Selain itu, profil disolusi masing-masing produk meunjukkan profil yang berbeda.

\section{Daftar Pustaka}

Anonim, 1995, Farmakope Indonesia, edisi IV, Departemen Kesehatan Republik Indonesia, Jakarta hal: 95-96,1004, 1083- 1085.

Anonim. 2002, Informasi Spesialite Obat Indonesia, Edisi Farmakoterapi, Ikatan Sarjana Farmasi Indonesia, p:50-64.

Anonim, 2003, The United States Pharmacopeia, $26 \mathrm{rd} \mathrm{Ed,1375,} \mathrm{The}$ US Pharmacopeial Convention Inc, Twinbook Parkway, Rockville, p:142-143

Anonim, 2005, Obat Generik Berlogo, vol. 01, Ikatan Sarjana Farmasi Indonesia, p: 9.

Anonim, 2008 , http://www.wikimedia.org/wikiped ia/commons/thumb, diakses pada tanggal 26 Pebruari 2011.

Ansel, H.C., Allen,L.V., and Popovich, N.G., 1999, Capsul and Tablets dalam Pharmaceutical Dosage and Drug Delivery System, Lippincott Williams and Wilkin, New York, pp: 208-218, 229-235.

Aryani, N.L.D., 2004, Pengaruh pH dan PVP K-30 Terhadap Sifat Fisikokimia Acetaminophen dan Uji Pelepasan serta Transpor Membran, Tesis, Program
Pascasarjana, Fak. Farmasi Univ. Gadjah Mada, Yogyakarta.

Banker, G.S. and Anderson, N.R., 1994, Tablets in Lachman, L., Lieberman, H.A., Kanig, J.L., The Theory and Practice of Industrial Pharmacy, $3^{\text {rd }}$ edition, 293-317, Lea and Febiger, Philadelphia.

Khan, K.A. and Rhodes, C.T., 1976, Comparative Evaluation of Some Direct Compression Diluent, Pharm. Acta Helv., 51, 23-26.

Lachman L., Lieberman, H. A., dan Kanig, J. L., 1986, Teori dan Praktek Farmasi Industri,Diterjemahkan oleh Siti Suyatmi, UI Press, Jakarta: Halaman 645-646, 674-679, 697699, 701-703.

Shargel, L., and Yu,A.B.C., 2005, Biofarmasetika dan Farmakokinetika Terapan, Ed 2,Airlangga University Press, Surabaya.

Siregar C.,1999, Teknologi Farmasi, Sediaan Solida, 27, Penerbit ITB, Bandung

Tjay,T.H., 2002, Obat Obat Penting Khasiat, Penggunaan dan Efek Efek Sampingnya, Elex Media Komputindo, p: 63-68. 